\title{
Antibacterial and antibiofilm activity of acetone leaf extracts of nine under- investigated south African Eugenia and Syzygium (Myrtaceae) species and their selectivity indices
}

\author{
Ibukun M. Famuyide', Abimbola O. Aro' ${ }^{1}$ Folorunso O. Fasina ${ }^{2,3}$, Jacobus N. Eloff ${ }^{* *}$ (i) and Lyndy J. McGaw
}

\begin{abstract}
Background: Antimicrobial resistance (AMR) remains an important global health issue but the gap between AMR and development of new antimicrobials is increasing. Plant extracts may have good activity per se or may be sources of effective antimicrobial compounds which can act against planktonic and/or biofilms of pathogens. We determined the antimicrobial efficacy and cytotoxicity of some under-investigated plants from the Myrtaceae family endemic to South Africa. The ability of the plant extracts to inhibit or destroy pre-formed bacterial biofilms was also determined.

Methods: Based on previous preliminary in vitro screening and on chemotaxonomy, nine species from the Myrtaceae family were selected. The antimicrobial activity of the crude acetone leaf extracts was determined against six common nosocomial pathogens, namely: Gram-positive bacteria (Bacillus cereus, Enterococcus faecalis, Staphylococcus aureus), Gramnegative bacteria (Escherichia coli, Pseudomonas aeruginosa, Salmonella Typhimurium) using a two-fold serial microdilution assay with p-iodonitrotetrazolium violet as growth indicator. The number of antimicrobial compounds present in extracts was determined by bioautography. Cytotoxicity of extracts was determined against Vero kidney cells using a colorimetric tetrazolium-based assay. The total antibacterial activity (TAA) in $\mathrm{ml} / \mathrm{g}$ and selectivity index ( $\left(\mathrm{C}_{50} / \mathrm{MIC}\right)$ of the plant extracts were calculated. A modified crystal violet assay was used to determine the antibiofilm activity of the extracts.

Results: Syzygium legatii, Syzygium masukuense, and Syzygium species A had the best activities against Gram-negative and Gram-positive bacteria (MIC) values ranging from $0.04-0.08 \mathrm{mg} / \mathrm{ml}$. Eugenia erythrophylla had the best MIC $(0.02 \mathrm{mg} / \mathrm{ml})$ against Bacillus cereus. Many extracts had relatively low cytotoxicity $\left(\mathrm{LC}_{50}>20 \mu \mathrm{g} / \mathrm{ml}\right)$ leading to reasonable selectivity indices. Three leaf extracts (Syzygium masukuense, Syzygium species A, and Eugenia natalitia) were moderately cytotoxic $(20 \mu \mathrm{g} / \mathrm{ml}<$ $\mathrm{LC}_{50}<100 \mathrm{\mu g} / \mathrm{ml}$ ). The plant extracts had a good capacity to reduce biofilm formation and good to poor potential to destroy pre-formed biofilms.

Conclusions: The plant species examined in this study had varying degrees of antibacterial activity against bacterial planktonic and biofilm forms with some having good activity against both forms. Several of these selected species may be potential candidates for further investigation to isolate antimicrobial compounds and to determine the mechanism of activity.
\end{abstract}

Keywords: Antibacterial activity, Antibiofilm activity, Cellular safety, Nosocomial bacteria, Myrtaceae, Syzygium, Eugenia

\footnotetext{
* Correspondence: kobus.eloff@up.ac.za

'Phytomedicine Programme, Faculty of Veterinary Science, University of

Pretoria, Private Bag X04, Onderstepoort 0110, South Africa

Full list of author information is available at the end of the article
}

(c) The Author(s). 2019 Open Access This article is distributed under the terms of the Creative Commons Attribution 4.0 International License (http://creativecommons.org/licenses/by/4.0/), which permits unrestricted use, distribution, and reproduction in any medium, provided you give appropriate credit to the original author(s) and the source, provide a link to the Creative Commons license, and indicate if changes were made. The Creative Commons Public Domain Dedication waiver (http://creativecommons.org/publicdomain/zero/1.0/) applies to the data made available in this article, unless otherwise stated. 


\section{Background}

Globally, antibiotics are used to treat infections in humans and animals. In addition to the therapeutic use in animals, antibiotics are commonly added to animal feeds in small quantities as a prophylaxis and for growth promotion purposes [1]. However, there has been a consistent rise in the resistance of microbes to antimicrobials and decreasing ability of the available antimicrobials to treat common infections.

Antimicrobial resistance (AMR) is a major threat to the health and well-being of people and animals with huge impact on food security [2]. However, the world is currently faced with the dilemma of a decline in the number of new therapeutic agents to treat various diseases in both humans and animals [3]. Society may be entering a post-antibiotic era with existing antibiotics gradually becoming ineffective due to resistance. This has major threats to health, as well as national security, for example pandemics and bioterrorism [4]. Current estimates reveal an annual death toll of 700,000 people due to antibiotic resistance and a projection that by 2050, 10 million lives may be at risk if nothing is done to halt the drift towards increasing AMR [5]. Moreover, people living in developing countries where significant morbidity and mortality are due to infectious diseases will be the worst hit by this situation [6].

In 2017, a comprehensive list of priority pathogens was released by the World Health Organization (WHO), including microbes such as Staphyloccocus aureus, Acinetobacter baumannii, Streptococcus pneumoniae, E. coli, Klebsiella spp., Enterobacter spp. etc. [7]. These pathogens have high levels of resistance to most existing antibiotics such as carbapenem, vancomyin, penicillin, ampicillin, and the third-generation antibiotic cephalosporin.

Biofilm formation is one of the resistance strategies of many pathogens which makes them more difficult to treat than their planktonic counterparts [8]. A biofilm is a complex matrix of communities of microorganisms composed of polysaccharides, proteins, and other organic components in which cells bind together to form strong attachments to biotic or abiotic surfaces [9]. Biofilms enable microbes that attach to a surface to persist even in the presence of harsh conditions such as natural host defenses and antimicrobial agents [10]. Therefore, biofilm formation is one of the indirect modes of action by which bacteria are resistant to antibiotics [11] and where they also transfer resistance genes within members of the biofilm micro-community [12]. Many species of bacterial genera of human and veterinary importance such as Escherichia, Staphylococcus, Pseudomonas, Pasteurella, Bacillus, Salmonella etc. cause infections that are difficult to treat due to their ability to form biofilms $[13,14]$. Biofilms could be involved in over $60 \%$ of microbial infections $[15,16]$ while two-thirds of all human bacterial infections are caused by the biofilms [17].
The need to tackle these problems coupled with the limited number of new antimicrobials gives enough motivation to increase the search for potential drugs and drug scaffolds from different sources [18]. Efforts focused on natural products research is a promising route of investigation because a significant percentage of new approved antibacterial are either natural products themselves, or natural product derivatives [19].

Plants are a rich reservoir of compounds that have numerous reported biological activities including antimicrobial properties [20-22] thereby becoming a good resource to explore for the discovery of useful and novel antimicrobial products. The World Health Organization also recognizes the place of plants as a mainstay of primary health for over half of the world's population especially in resource poor countries [23]. Natural products from plants have been recognized as a useful resource that may serve as leads to the discovery of new antimicrobial substances with possible new mechanisms of action. Bioactive plant-based products have the potential to promote the health of animals when included as feed and food components [24].

South Africa is home to a large diversity of plants and many people use plants to meet their health care either due to limited access to Western medicines, particularly in the rural areas, or as adjuncts to conventional medicine even when there is access [6].

We decided to focus our study on plants from the Myrtaceae family because of the promising antimicrobial activities observed in a preliminary evaluation of plants from this family. An extensive study [25] reported that species in the same order and family have a higher chance of yielding interesting antimicrobial compounds. Therefore, selection based on this may be better than from traditional leads alone. Water is the only extractant available to most traditional healers but water does not extract the major bioactive compounds which are usually intermediately polar to non-polar [26, 27].

The Myrtaceae family is globally distributed, consisting of about 145 genera and over 500 known species [28]. Many species belonging to the Eugenia and Syzygium genera have been used traditionally to treat different ailments such as diarrhoea, diabetes, reproductive problems, and respiratory conditions $[29,30]$. Many studies have reported various pharmacological properties in members of these genera including antimicrobial [31, 32], antiinflammatory [33], antitumor [34], antioxidant [35] and antidiabetic [36]. Apart from medicinal uses, the plants are commercially explored for their edible fruits, essential oils and for ornamental purposes [31, 37]. There are few or no reports of the biological activity and phytochemistry of the species that we have selected. These plants are largely under-explored for their potential antimicrobial properties. Our research focus is to select plants which may hold potential for development as phytogenic feed 
additives in combating diarrhoea in livestock management. In this study, we determined the antibacterial activity of acetone crude leaf extracts of nine plant species from the Myrtaceae family native to South Africa against three Gram-positive (Bacillus cereus, Staphylococcus aureus, Enterococcus faecalis) and three Gram-negative (Escherichia coli, Pseudomonas aeruginosa, Salmonella Typhimurium) bacteria. We also determined the cytotoxicity of the extracts since safety is important in consideration for further studies. Furthermore, we investigated the antibiofilm activity of the extracts on the six pathogens to either prevent formation or destroy pre-formed bacterial biofilms because it is an important strategy for microbial persistence in living and non-living tissues.

\section{Methods}

\section{Collection of plant material, drying and storage}

Healthy leaves of nine species from the Myrtaceae family were collected in the summer of 2017, at the Lowveld National Botanical Garden in Nelspruit, Mpumalanga, South Africa. The identities of the plants were verified by Ms. Magda Nel from the Department of Plant and Soil Science, University of Pretoria. Voucher specimens were prepared and deposited in the HGWJ Schweickerdt Herbarium of the University of Pretoria and voucher specimen numbers (PRU) were obtained. The plants selected for this study were: Eugenia erythrophylla Strey (PRU 123616), Eugenia natalitia Sond. (PRU 123613), Eugenia woodii Dummer (PRU 123615), Eugenia untamvunensis A.E.van Wyk (PRU 123618), Eugenia zeyheri (Harv.) Harv. (PRU 123617), Syzygium legatii Burtt Davy \& Greenway (PRU 123619), Syzygium masukuense subsp. masukuense (PRU 123623), Syzygium species A (PRU 123622) and Syzygium gerrardii (Harv. Ex Hook.f.) Burtt Davy (PRU 123620). Syzygium species A could not be identified by the plant taxonomists and may be a new species. Several of these species may be threatened or endangered. Therefore, we did not collect plant material in the veld but only in good botanical gardens with known provenance of the plants. Furthermore, we only investigated leaf material to ensure that it is a sustainable resource.

Methods which were previously developed in the Phytomedicine Programme [38] were used to process the plants. Briefly, leaves were harvested and transported in open mesh loose woven bags into the laboratory. Leaves attacked by microbes or insects were removed and the rest were air-dried indoors at room temperature with good airflow to reduce any microbial attack as well as to facilitate grinding. The dried leaves were then ground to a fine powder using a Janke and Künkel homogenizer Model A10 mill. The leaf powders were weighed and stored in closed glass containers in the dark at room temperature.

\section{Extraction}

Acetone was used as the solvent of choice to extract the powdered leaves as well as to prepare the plant concentrations for the bioassays. Extraction with acetone is considered the best choice because it can extract compounds of a wide range of polarities, it is nontoxic to bioassay systems and easy to remove from extracts [39]. Two grams of ground dry leaf samples were extracted with $20 \mathrm{~mL}$ acetone. The mixture was sonicated for $20 \mathrm{~min}$, vigorously shaken, and then poured into a $50 \mathrm{ml}$ polyester centrifuge tube and centrifuged at $4000 \mathrm{x}$ g for $10 \mathrm{~min}$ (Hettich Centrifuge, Rotofix 32 A, Labotec, Johannesburg, South Africa). The supernatant was collected and filtered through Whatman No. 1 filter paper into pre-weighed glass vials and concentrated by drying under a stream of cold air. The dried extracts were weighed and the yield obtained by dividing the mass extracted by the initial mass. A concentration of $10 \mathrm{mg} / \mathrm{mL}$ (stock solution) in acetone was prepared for use in the assays.

\section{Analysis of extract by thin layer chromatography (TLC)}

Qualitative screening of crude acetone extracts was performed to obtain thin layer chromatography (TLC) fingerprints on aluminum-backed silica gel plates following an established protocol [26]. Three different solvent systems of diverse polarities namely benzene: ethanol: ammonium hydroxide (18,2:0.2, BEA, non-polar basic); chloroform: ethylacetate: formic acid (5,4:1, CEF, intermediate polarity, acidic) and ethylacetate: methanol: water (40,5.4:5, EMW, polar, neutral) were used to elute $100 \mu \mathrm{g}$ of the extract loaded in a band of $1 \mathrm{~cm}$ width on the TLC plates. Visible bands were marked under white light and ultraviolet light $(254 \mathrm{~nm}$ and $360 \mathrm{~nm}$ wavelengths, Camac universal UV light lamp TL$600)$ and then sprayed with freshly prepared vanillin $(0.1 \mathrm{~g}$ vanillin, $28 \mathrm{~mL}$ methanol, $1 \mathrm{~mL}$ sulphuric acid) spray reagent. The plates were then heated to $110^{\circ} \mathrm{C}$ until optimal colour development.

\section{Antibacterial screening Qualitative antibacterial assay by TLC bioautography}

To determine the number of antimicrobial compounds in the extracts, bioautograms of the extracts were prepared as described above except that the plates were not sprayed with vanillin. The plates were allowed to dry overnight in a stream of cold air to remove the eluents. The plates were then each sprayed with an actively growing suspension of either $E$. coli, S. aureus or B. cereus cultured for $18-24 \mathrm{~h}$ at $37^{\circ} \mathrm{C}$ until they were wet. The moist plates were then allowed to dry and incubated at $37^{\circ} \mathrm{C}$ in a closed plastic humidified sterile container for $24 \mathrm{~h}$ to allow the bacteria to grow on the plates. After incubation, the plates were sprayed with $2 \mathrm{mg} / \mathrm{mL}$ of freshly prepared p-iodonitrotetrazolium (INT) violet (Sigma) in sterile distilled water and incubated further for $1-2 \mathrm{~h}$ for the development of clear zones against a purple-red background which 
suggests inhibition of bacterial growth by the compounds separated on the chromatograms [40].

\section{Quantitative antibacterial assay by minimum inhibitory assay}

A widely accepted, simple, reproducible, low cost, and sensitive serial dilution microplate method with INT as indicator of growth [41] was used to determine the minimum inhibitory concentration (MIC) of the crude plant extracts against six bacterial strains in triplicate in three independent experiments. Bacterial cultures were grown overnight in Mueller Hinton broth (Sigma Aldrich, SA) and adjusted to McFarland standard 1 which is equivalent to c. $3.0 \times 10^{8} \mathrm{cfu} / \mathrm{mL}$ (Staphylococcus aureus, ATCC 29213), $2.1 \times 10^{8} \mathrm{cfu} / \mathrm{mL}$ (Enterococcus faecalis, ATCC 29212), $1.3 \times 10^{8} \mathrm{cfu} / \mathrm{mL}$ (Bacillus cereus, ATCC 21366), $3.7 \times 10^{8} \mathrm{cfu} / \mathrm{mL}$ (Escherichia coli, ATCC 25922), $3.5 \times$ $10^{8} \mathrm{cfu} / \mathrm{mL}$ (Salmonella Typhimurium, ATCC 39183) and $3.2 \times 10^{8} \mathrm{cfu} / \mathrm{mL}$ (Pseudomonas aeruginosa, ATCC 27853). The dried extracts were dissolved in acetone to a concentration of $10 \mathrm{mg} / \mathrm{mL}$ and $100 \mu \mathrm{l}$ was added to the first well of a sterile 96-well microtitre plate containing $100 \mu \mathrm{l}$ of water and serially diluted 1:1 with sterile distilled water. One hundred microliters of appropriately adjusted bacterial cultures were added to each well. The bacteria were subjected to final extract concentrations of $2.5,1.25,0.63,0.32,0.16,0.08,0.04$ and $0.02 \mathrm{mg} / \mathrm{mL}$. Gentamicin (Virbac)at the same concentrations as the plant extracts and acetone served as positive and negative controls respectively while water served as sterility control. The bacteria were subjected to decreasing concentrations of acetone starting with $25 \%$ in the first well with a two-fold decrease in subsequent wells. It has been established that acetone at these concentrations did not inhibit microbial growth [42]. The microplates were then incubated at $37^{\circ} \mathrm{C}$ for $18-24 \mathrm{~h}$. After incubation, the plates were removed from the incubator and $40 \mu \mathrm{l}$ of 0.2 $\mathrm{mg} / \mathrm{mL}$ INT dissolved in hot water was added to the wells and incubated further at $37^{\circ} \mathrm{C}$ for $2 \mathrm{~h}$. The MIC was determined visually as the lowest concentration that led to growth inhibition [41]. Additionally, the total activity $(\mathrm{mL} / \mathrm{g})$ of the extracts was calculated by dividing the mass in mg extracted from $1 \mathrm{~g}$ of plant material with the MIC in $\mathrm{mg} / \mathrm{mL}$ [43]. The total activity incorporates the mass extracted as well as the antibacterial activity and is used to compare the potential use of extracts of different plant species.

\section{Antibiofilm screening Inhibition of biofilm formation - prevention of initial bacterial cell attachment}

The potential of the extracts to prevent initial cell attachment was investigated through the biofilm inhibition assay [44]. Briefly, a $100 \mu \mathrm{l}$ aliquot of standardised concentration of cultures with $\mathrm{OD}_{560}=0.02\left(1.0 \times 10^{6} \mathrm{CFU} / \mathrm{mL}\right)$ of Pseudomonas aeruginosa (ATCC 27853), Salmonella Typhimurium (ATCC 39183), Staphylococcus aureus (ATCC 29213), Enterococcus faecalis (ATCC 29212), Escherichia coli (ATCC 25922) or Bacillus cereus (ATCC 21366) was added into individual flat-bottomed 96-well microtitre plates and incubated at $37^{\circ} \mathrm{C}$ for $4 \mathrm{~h}$ without shaking. Then the plates were removed from the incubator and $100 \mu \mathrm{l}(2 \mathrm{mg} / \mathrm{ml})$ aliquots of plant extracts were added in twelve replicates into the wells of 96-well microtitre plates to give a final concentration of $1 \mathrm{mg} / \mathrm{mL}$ and then incubated further at $37^{\circ} \mathrm{C}$ for $24 \mathrm{~h}$ without agitation. Gentamicin (Virbac) served as positive control while acetone and sterile distilled water served as negative controls. The biomass was quantified using the modified crystal violet staining method [45].

\section{Inhibition of development of pre-formed biofilms - assessment of destruction of biofilm mass}

The ability of the extracts to prevent further biofilm development or destruction of pre-formed biofilms was investigated. A $100 \mu \mathrm{l}$ aliquot of standardised concentration of cultures with $\mathrm{OD}_{560}=0.02\left(1.0 \times 10^{6} \mathrm{CFU} / \mathrm{ml}\right)$ of Pseudomonas aeruginosa (ATCC 27853), Salmonella Typhimurium (ATCC 39183), Staphylococcus aureus (ATCC 29213), Enterococcus faecalis (ATCC 29212), Escherichia coli (ATCC 25922) or Bacillus cereus (ATCC 21366) was added into individual flat-bottomed 96-well microtitre plates and incubated at $37^{\circ} \mathrm{C}$ for $24 \mathrm{~h}$ (irreversible attachment phase) or $48 \mathrm{~h}$ (mature biofilm) without shaking for the development of a multilayer biofilm. Following respective incubation periods, $100 \mu \mathrm{l}$ aliquots of plant extracts $(2 \mathrm{mg} / \mathrm{mL})$ were added into the wells of a 96-well microtitre plates to give a final concentration of $1 \mathrm{mg} / \mathrm{mL}$ and the plates were incubated further at $37^{\circ} \mathrm{C}$ for $24 \mathrm{~h}$. Gentamicin (Virbac) at the same concentration as the extracts served as positive control while both acetone and sterile distilled water served as negative controls. The biofilm biomass was assayed using the modified crystal violet (CV) staining assay [45].

\section{Crystal violet staining assay}

The assay was done as previously described [45] with some modifications [44]. Briefly, the 96-well microtitre plates were washed five times with sterile distilled water, air dried and then oven-dried at $60^{\circ} \mathrm{C}$ for $45 \mathrm{~min}$. The wells were then stained with $100 \mu \mathrm{l}$ of $1 \%$ crystal violet and incubated at room temperature for $15 \mathrm{~min}$ after which the plates were washed thrice with sterile distilled water to remove unabsorbed stain. At this point, biofilms were observed as purple rings at the side of the wells. The semi-quantitative assessment of biofilm formation was done by adding $125 \mu \mathrm{l}$ of ethanol to destain the wells. A $100 \mu \mathrm{l}$ aliquot of the destaining solution was transferred to a new sterile plate and the absorbance was 
measured at $590 \mathrm{~nm}$ using a microplate reader (BioTek Synergy). The mean absorbance of the samples was determined, and percentage inhibition of biofilm was determined using the equation below [44]:

Percentage $(\%)$ inhibition $=\frac{\mathrm{OD}_{\text {Negative control }}-\mathrm{OD}_{\text {Experimental }} \times 100}{\mathrm{OD}_{\text {Negative control }}}$

Although it was not done in the procedure we followed, it would have been interesting to determine if the cells in the biofilm were still viable by using not only the crystal violet assay but also by using e.g. XTT in a different assay. Using this would have enabled us to compare the effect of the plant extracts that generally had an MIC at least ten times lower that the concentration used in the biofilm assay on cells in the biofilm.

\section{Cytotoxicity}

The cellular toxicity of the crude plant extracts to Vero African green monkey kidney cells obtained from the collection of the Department of Veterinary Tropical Diseases, University of Pretoria, was determined using the 3-(4,5-dimethylthiazol)-2,5-diphenyl tetrazolium bromide (MTT) assay [46] with minor modifications [47]. The cells were maintained in minimal essential medium (MEM, Highveld Biological, South Africa) supplemented with $5 \%$ foetal calf serum (Adcock-Ingram) and $0.1 \%$ gentamicin (Virbac) in a $5 \% \mathrm{CO}_{2}$ incubator. Cell suspensions were prepared from 70 to $80 \%$ confluent monolayer cultures and plated at a density of $5 \times 10^{4}$ cells into each well of sterile flat-bottomed 96-well microtitre cell culture plates. Plates were incubated for $24 \mathrm{~h}$ at $37^{\circ} \mathrm{C}$ in a $5 \% \mathrm{CO}_{2}$ incubator before exposure to the extracts. The crude plant extracts were dissolved in acetone $(100 \mathrm{mg} /$ $\mathrm{mL}$ ), and appropriate dilutions were prepared in MEM and added to the wells. Cells were exposed to the various concentrations $(0.025$ to $1 \mathrm{mg} / \mathrm{ml})$ of plant extracts for $48 \mathrm{~h}$. Doxorubicin (Pfizer) and acetone served as positive and negative controls respectively. After incubation for $48 \mathrm{~h}$, the wells were rinsed twice with $200 \mu \mathrm{l}$ of phosphate buffered saline (PBS, Sigma) and $200 \mu \mathrm{l}$ of fresh medium was dispensed into the wells. Then $30 \mu \mathrm{l}$ $(5 \mathrm{mg} / \mathrm{ml}$ ) of MTT (Sigma) dissolved in PBS was added to each well and the plates were further incubated for 4 $\mathrm{h}$ at $37^{\circ} \mathrm{C}$. After this, the medium from the wells was discarded and $50 \mu \mathrm{l}$ of DMSO was added to the wells to dissolve the formed formazan crystals. Absorbance was measured on a microplate reader (BioTek Synergy) at a wavelength of $570 \mathrm{~nm}$. Each extract concentration was tested in quadruplicate and the assay was repeated three times. The concentration causing $50 \%$ inhibition of cell viability $\left(\mathrm{LC}_{50}\right)$ was calculated. Selectivity index (SI) values for the extracts were calculated by dividing cytotoxicity $\mathrm{LC}_{50}$ values by the MIC values $\left(\mathrm{LC}_{50} / \mathrm{MIC}\right)$.

\section{Statistical analysis}

Experimental results were expressed as mean \pm standard error of mean (SEM) of at least three replicates. Where applicable, differences between samples and control were analyzed using one-way analysis of variance (ANOVA) and the significant difference between the means was tested using the Dunnett's or Tukey's multiple comparison. Graphpad Instat 6.0 software was used to analyze the data.

\section{Results}

\section{Plant extracts yield}

The yields of the acetone crude leaf extracts of the nine plants is given Table 1. Eugenia zeyheri had the highest yield (25.33\%) followed by E. erythrophylla (18.50\%) while E. umtamvunensis gave the lowest yield (8.77\%).

Table 1 Yield of extract, minimum inhibitory concentration (MIC) and total antibacterial activity (TAA) of the nine selected acetone leaf extracts against Gram-positive test bacteria. Values equal to or less than $0.1 \mathrm{mg} / \mathrm{ml}$ indicate high activity

\begin{tabular}{|c|c|c|c|c|c|c|c|}
\hline \multirow[b]{2}{*}{ Plant } & \multirow[b]{2}{*}{$\%$ yield } & \multicolumn{2}{|c|}{ Enterococcus faecalis } & \multicolumn{2}{|l|}{ Bacillus cereus } & \multicolumn{2}{|c|}{ Staphylococcus aureus } \\
\hline & & MIC $(\mathrm{mg} / \mathrm{ml})$ & TAA $(\mathrm{ml} / \mathrm{g})$ & $\mathrm{MIC}(\mathrm{mg} / \mathrm{ml})$ & TAA $(\mathrm{ml} / \mathrm{g})$ & $\mathrm{MIC}(\mathrm{mg} / \mathrm{ml})$ & TAA $(\mathrm{ml} / \mathrm{g})$ \\
\hline Eugenia erythrophylla & 18.50 & $0.31 \pm 0.00$ & 591.05 & $0.02 \pm 0.00$ & 9250.00 & $0.08 \pm 0.00$ & 2371.79 \\
\hline Eugenia natalitia & 9.40 & $0.08 \pm 0.00$ & 1205.13 & $0.08 \pm 0.00$ & 1205.13 & $0.16 \pm 0.00$ & 602.56 \\
\hline Eugenia woodii & 9.80 & $0.63 \pm 0.00$ & 156.80 & $0.16 \pm 0.00$ & 628.21 & $0.08 \pm 0.00$ & 1256.41 \\
\hline Eugenia umtamvunensis & 8.77 & $0.16 \pm 0.00$ & 561.97 & $0.04 \pm 0.00$ & 2247.86 & $0.08 \pm 0.00$ & 1123.93 \\
\hline Eugenia zeyheri & 25.33 & $1.25 \pm 0.00$ & 202.67 & $0.08 \pm 0.00$ & 3247.86 & $0.08 \pm 0.00$ & 3247.86 \\
\hline Syzygium legatii & 9.23 & $0.08 \pm 0.00$ & 1183.76 & $0.03 \pm 0.01$ & 2797.98 & $0.08 \pm 0.00$ & 1183.76 \\
\hline Syzygium masukuense & 10.50 & $0.04 \pm 0.00$ & 2692.31 & $0.08 \pm 0.00$ & 1346.15 & $0.16 \pm 0.00$ & 673.08 \\
\hline Syzygium species A & 10.65 & $0.04 \pm 0.00$ & 2730.77 & $0.16 \pm 0.00$ & 682.69 & $0.04 \pm 0.00$ & 2730.77 \\
\hline Syzygium gerrardii & 17.00 & $0.16 \pm 0.00$ & 1088.00 & $0.04 \pm 0.00$ & 4352.00 & $0.08 \pm 0.00$ & 2176.00 \\
\hline Gentamicin & NA & 0.002 & NA & 0.0005 & NA & 0.00013 & NA \\
\hline Average for extracts & NA & $0.3 \pm 0.38$ & NA & $0.08 \pm 0.05$ & NA & $0.09 \pm 0.04$ & NA \\
\hline
\end{tabular}

The values in bold indicate good activity 


\section{Bioautography}

Of the three solvents used for elution of TLC plates, the intermediate solvent system (CEF) gave the best separation of compounds against $E$. coli (Fig. 1). The retention factor $\left(R_{\mathrm{f}}\right)$ of the active compounds was obtained by dividing the distance moved by the compound by the solvent distance. Four compounds with $\mathrm{R}_{\mathrm{f}}$ values $0.91,0.65$, 0.59 and 0.56 were observed in $S$. masukuense and $S$. species A while these compounds apart from one compound at $R_{f}=0.59$ were present in six of the remaining plants. No clear zone was visible for $S$. gerrardii at the tested concentration indicating that no separated compounds had activity in this assay.

\section{Antibacterial activity (minimum inhibitory concentration values) and total antibacterial activity}

The antibacterial activity of the nine acetone plant extracts in given in Tables 1 and 2. Results showed that the plant extracts were active against the tested bacteria. The MIC values for the extracts ranged between $0.04-0.31 \mathrm{mg} / \mathrm{mL}$ for Gram-negative bacteria (Table 2) and $0.02-1.25 \mathrm{mg} / \mathrm{mL}$ for Gram-positive bacteria (Table 2). Bacillus cereus with a mean MIC of 0.08 (Table 1) was the most susceptible of the Gram-positive bacteria. Of the Gram-negative bacteria, $S$. Typhimurium and $P$. aeruginosa, (mean MICs of $0.14 \mathrm{mg} / \mathrm{ml}$ ), and E. coli (mean $\mathrm{MIC}=0.16$ $\mathrm{mg} / \mathrm{mL}$ ) were the most susceptible. The total antibacterial activity of each of the plant extract, which was obtained by dividing the quantity extracted from one gram of each plant extract by the MIC value is shown in Tables 1 and 2. Eugenia erythrophylla, S. gerrardii, S. species A, and E. zeyheri had the highest mean total antibacterial activities of 2628, 2267, 1939 and $1846 \mathrm{~mL} / \mathrm{g}$ respectively (Fig. 2).

\section{Cytotoxicity}

The cytotoxicity activity against Vero cells and their selectivity indices of the nine selected acetone crude extracts is given in Table 3. Eugenia natalitia had the highest cytotoxicity $\left(\mathrm{LC}_{50}=38 \pm 0.01 \mu \mathrm{g} / \mathrm{mL}\right)$ followed by $S$. species A $(61 \pm 0.004 \mu \mathrm{g} / \mathrm{mL})$, and S. masukuense $(70 \pm 0.01 \mu \mathrm{g} / \mathrm{mL})$. All the other plant extracts had $\mathrm{LC}_{50}$ values greater than $100 \mu \mathrm{g} / \mathrm{mL}$. The cytotoxicity $(\mathrm{mg} / \mathrm{mL})$ and MIC $(\mathrm{mg} / \mathrm{mL})$ values are the two variables used to calculate the selectivity index (SI) of a plant extract $\left(\mathrm{SI}=\mathrm{LD}_{50} / \mathrm{MIC}\right)$, which is a measure of the safety margin of the extract [48]. In this study, Eugenia zeyheri had the best average selectivity index of 8.27 against all the pathogens (Table 3) followed by E. umtamvunensis (7.90), E. erythrophylla (3.53), S. gerrardii (2.66) and S. legatii (2.44). E. natalitia had a poor selectivity index of 0.36 .

\section{Prevention of cell attachment: antibiofilm activity/ anti- adhesion}

The effect of acetone crude extracts on the attachment and inhibition of biofilm formation is given in Table 4. According to established criteria [44], percentage inhibition values between 0 to $100 \%$ signify inhibition of biofilm, while enhancement of growth is reflected by values below $0 \%$. Above the $50 \%$ inhibition mark the activity is regarded as good, while it is poor if it is between 0 and $49 \%$.

The plant extracts had varying degrees of activity on the prevention of attachment. Four of the extracts had good prevention of biofilm attachment against E. coli (> $50 \%$ ), three extracts had inhibition less than $50 \%$ while the extracts of $E$. woodii and $S$. gerrardii enhanced the biofilm growth and hence were not included in the biofilm development assay.

All plant extracts from the Eugenia species prevented attachment of $P$. aeruginosa with values above $50 \%$. Apart from S. legatii, no Syzygium species inhibited cell
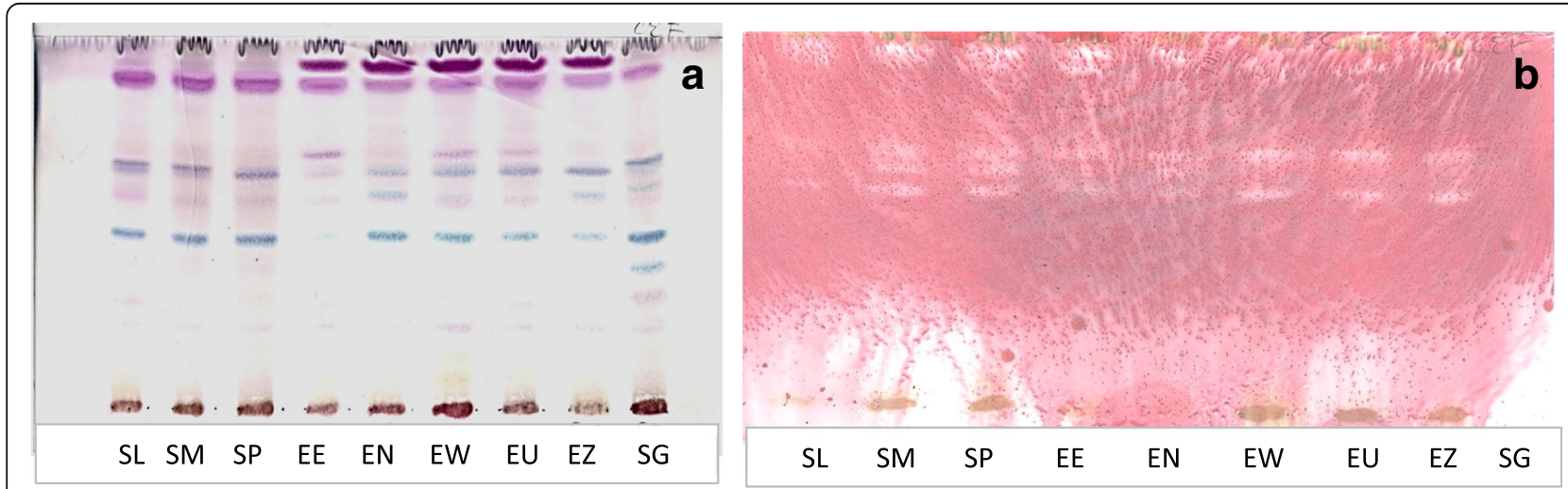

Fig. 1 a Chromatogram developed in chloroform: ethyl acetate: formic acid (CEF) solvent system of the acetone leaf extracts of the nine plants sprayed with vanillin. b Bioautography of Escherichia coli developed with CEF; white bands indicate compounds that inhibit the growth of the bacteria. SL = Syzygium legatii, SM = Syzygium masukuense, SP = Syzygium species A, SG = Syzygium gerrardii, ER= Eugenia erythrophylla, EN = Eugenia natalitia, EW = Eugenia woodii, EU = Eugenia umtamvunensis, EZ = Eugenia zeyheri 
Table 2 Yield of extract, Minimum Inhibitory Concentration (MIC) and total antibacterial activity (TAA) of the nine selected acetone leaf extracts against Gram-negative test bacteria. Values equal to or less than $0.1 \mathrm{mg} / \mathrm{ml}$ indicate high activity

\begin{tabular}{|c|c|c|c|c|c|c|c|}
\hline \multirow[b]{2}{*}{ Plant } & \multirow[b]{2}{*}{$\%$ yield } & \multicolumn{2}{|c|}{ Escherichia coli } & \multicolumn{2}{|c|}{ Pseudomonas aeruginosa } & \multicolumn{2}{|c|}{ Salmonella Typhimurium } \\
\hline & & $\overline{\mathrm{MIC}}(\mathrm{mg} / \mathrm{ml})$ & TAA $(\mathrm{ml} / \mathrm{g})$ & $\mathrm{MIC}(\mathrm{mg} / \mathrm{ml})$ & TAA $(\mathrm{ml} / \mathrm{g})$ & $\mathrm{MIC}(\mathrm{mg} / \mathrm{ml})$ & $\overline{\text { TAA }(\mathrm{ml} / \mathrm{g})}$ \\
\hline Eugenia erythrophylla & 18.50 & $0.10 \pm 0.05$ & 1778.85 & $0.16 \pm 0.00$ & 1185.90 & $0.31 \pm 0.00$ & 591.05 \\
\hline Eugenia natalitia & 9.40 & $0.16 \pm 0.00$ & 602.56 & $0.08 \pm 0.00$ & 1205.13 & $0.16 \pm 0.00$ & 602.56 \\
\hline Eugenia woodii & 9.80 & $0.16 \pm 0.00$ & 628.21 & $0.16 \pm 0.00$ & 628.21 & $0.08 \pm 0.00$ & 1256.41 \\
\hline Eugenia umtamvunensis & 8.77 & $0.31 \pm 0.00$ & 281.15 & $0.16 \pm 0.00$ & 564.10 & $0.31 \pm 0.00$ & 281.15 \\
\hline Eugenia zeyheri & 25.33 & $0.13 \pm 0.05$ & 1946.15 & $0.31 \pm 0.00$ & 808.31 & $0.16 \pm 0.00$ & 1621.79 \\
\hline Syzygium legatii & 9.23 & $0.08 \pm 0.00$ & 1179.49 & $0.08 \pm 0.00$ & 1179.49 & $0.04 \pm 0.00$ & 2358.97 \\
\hline Syzygium masukuense & 10.50 & $0.08 \pm 0.00$ & 1346.15 & $0.08 \pm 0.00$ & 1346.15 & $0.08 \pm 0.00$ & 1346.15 \\
\hline Syzygium species A & 10.65 & $0.08 \pm 0.00$ & 1371.79 & $0.08 \pm 0.00$ & 1371.79 & $0.04 \pm 0.00$ & 2743.59 \\
\hline Syzygium gerrardii & 17.00 & $0.31 \pm 0.00$ & 544.00 & $0.16 \pm 0.00$ & 1088.00 & $0.04 \pm 0.00$ & 4352.00 \\
\hline Gentamicin & NA & 0.0008 & NA & 0.0003 & NA & 0.0002 & NA \\
\hline Average for extracts & NA & $0.16 \pm 0.09$ & NA & $0.14 \pm 0.07$ & NA & $0.13 \pm 0.38$ & NA \\
\hline
\end{tabular}

attachment but rather enhanced biofilm formation based on the observed negative percentage inhibition values.

All the extracts, at inhibition $>0 \%$, prevented attachment of $S$. Typhimurium although the activity of $E$. woodii and E. zeyheri was below 50\%.

Six out of the nine plant extracts evaluated against $E$. faecalis prevented cell attachment while E. woodii, E. zeyheri, and $S$. species A enhanced biofilm attachment and growth.

In this study, all the plant extracts prevented the attachment of B. cereus although E. natalitia and S. masukuense had values lower than 50\% (Table 4).

Of the nine extracts tested against S. aureus, only S. masukuense and $S$. species A extracts did not prevent the

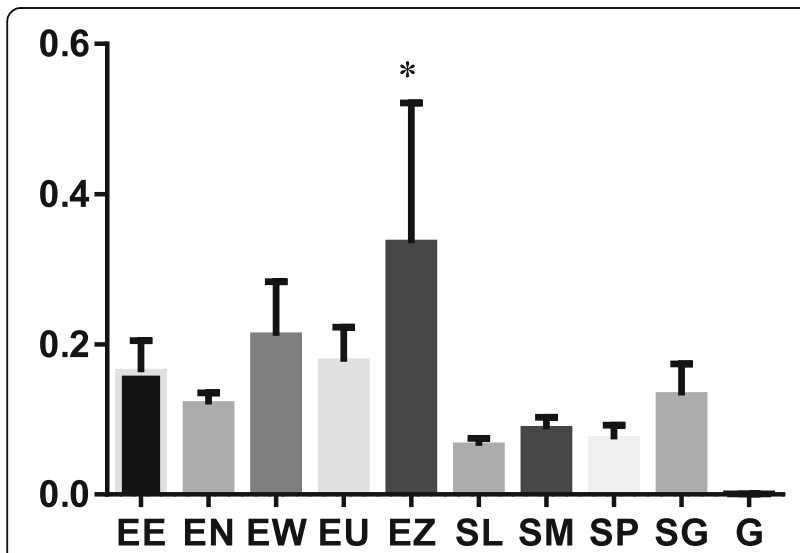

Fig. 2 The mean MIC in $\mathrm{mg} / \mathrm{ml}$ of the acetone leaf extracts of the nine plants against six different bacterial species. $\mathrm{EE}=$ Eugenia erythrophylla, EN = Eugenia natalitia, EW = Eugenia woodii, EU = Eugenia umtamvunensis, EZ = Eugenia zeyheri, SL = Syzygium legatii, $\mathrm{SM}=$ Syzygium masukuense, $\mathrm{SP}=$ Syzygium sp., $\mathrm{SG}=$ Syzygium gerrardii, $\mathrm{G}=$ Gentamicin (positive control). The negative control (acetone) was higher than 25\% (higher than $198 \mathrm{mg} / \mathrm{ml}) .{ }^{*}=$ shows statistical significant differences $(p<0.05)$ between Gentamicin and Eugenia zeyheri attachment of the bacteria although these two plants had good MICs (Table 1). Eugenia natalitia and E. woodii extracts, however had poor activity with values between 0 and $50 \%$.

\section{Inhibition of development of pre-formed biofilms - assessment of destruction of biofilm mass}

The activities of plant extracts with good anti-cell attachment properties on the prevention or reduction of further biofilm development in 24 and $48 \mathrm{~h}$ preformed biofilms are presented in Table 5 .

Of the seven plant extracts evaluated, five plant extracts reduced $E$. coli biofilm biomass at $24 \mathrm{~h}$ post-development (Table 5). Out of these five, three (E. natalitia, E. zeyheri and $S$. masukuense) had percentage inhibition values above $50 \%$. After $48 \mathrm{~h}$ pre-formed biofilm, E. umtamvunensis extracts had poor antibiofilm activity (28\%) while $S$. masukuense and $S$. species A prevented biofilm development by over $50 \%$ while the remaining extracts showed enhancement of biofilm. None of the plant extracts was able to destroy the biofilm of $P$. aeruginosa.

Antibiofilm activity against $S$. Typhimurium showed that after a $24 \mathrm{~h}$ pre-formed biofilm, E. woodii, E. umtamvunensis and $S$. species A had poor biofilm inhibiting activity of 29 , 33 , and $43 \%$ respectively while E. natalitia, E. zeyheri, $S$. masukuense, and S. gerrardii had good (> 50\%) antibiofilm activity. Eugenia erythrophylla and S. legatii enhanced biofilm formation at this period. In contrast, E. umtamvunensis, E. zeyheri, S. masukuense and S. species A had good antibiofilm activity after a $48 \mathrm{~h}$ pre-formed biofilm.

Of the six plants investigated, four reduced the $24 \mathrm{~h} \mathrm{E}$. faecalis biofilms and out of these, only $S$. gerrardii was active against the $48 \mathrm{~h}$ pre-formed biofilm (Table 5).

In the activity against B. cereus (Table 5), of all the investigated plants, S. masukuense had some activity, albeit poor, against the 24-h biofilm but had improved activity in the 48 $\mathrm{h}$ pre-formed biofilm. Also, $S$. species A enhanced of biofilm 
Table 3 Cytotoxicity against Vero cells $L_{50}(\mu \mathrm{g} / \mathrm{ml})$ and Selectivity index of the nine selected acetone crude extracts. Selectivity index values more than 1 are non-toxic extracts with a relatively good safe margin and promising antibacterial agents

\begin{tabular}{|c|c|c|c|c|c|c|c|c|}
\hline & \multicolumn{8}{|c|}{ Selectivity index } \\
\hline & Cytotoxicity & E. faecalis & B. cereus & S. aureus & E. coli & P. aeruginosa & S. typhimurium & Average \\
\hline E. erythrophylla & $250 \pm 0.06$ & 0.78 & 12.55 & 3.14 & 2.35 & 1.57 & 0.78 & 3.53 \\
\hline E. natalitia & $38 \pm 0.01$ & 0.48 & 0.48 & 0.24 & 0.24 & 0.48 & 0.24 & 0.36 \\
\hline E. woodii & $202 \pm 0.001$ & 0.32 & 1.29 & 2.59 & 1.29 & 1.29 & 2.59 & 1.56 \\
\hline E. umtamvunensis & $820 \pm 0.05$ & 5.27 & 21.07 & 10.54 & 2.63 & 5.27 & 2.63 & 7.90 \\
\hline E. zeyheri & $1140 \pm 0.17$ & 0.91 & 14.53 & 14.53 & 8.72 & 3.63 & 7.27 & 8.27 \\
\hline S. legatii & $140 \pm 0.05$ & 1.74 & 4.18 & 1.74 & 1.74 & 1.74 & 3.48 & 2.44 \\
\hline S. masukuense & $70 \pm 0.01$ & 1.87 & 0.94 & 0.47 & 0.94 & 0.94 & 0.94 & 1.02 \\
\hline S. species A & $61 \pm 0.004$ & 1.57 & 0.39 & 1.57 & 0.79 & 0.79 & 1.57 & 1.11 \\
\hline S. gerrardii & $200 \pm 0.03$ & 5.11 & 1.28 & 2.56 & 0.64 & 1.28 & 5.11 & 2.66 \\
\hline Doxorubicin & $12.07 \pm 0.41$ & ND & ND & ND & ND & ND & ND & ND \\
\hline
\end{tabular}

formation at $24 \mathrm{~h}$ but had some inhibition against the $48-\mathrm{h}$ biofilm. Syzygium gerrardii was only effective in reducing the $24 \mathrm{~h}$ biofilm but was not active against the 48 -h biofilm. Like $P$. aeruginosa, most of the plant extract did not have any effect on B. cereus biofilms at $24 \mathrm{~h}$ and $48 \mathrm{~h}$.

The extracts of E. umtamvunensis, S. legatii and S. gerrardii had inhibitions of above $50 \%$ against $24 \mathrm{~h} S$. aureus biofilm, E. erythrophylla had poor activity while others showed biofilm enhancement. Syzygium gerrardii had a good activity against $S$. aureus 48 h biofilm.

\section{Discussion}

The yield of a plant extract is important in calculating the total activity to compare plants for bioprospecting [43]. Bioautography was used to separate the antibacterial compound(s) present in plant extracts to provide more information on the diversity of the antibacterial compounds in the different plant species extracts. Active compounds in the plant extracts were mostly present in the intermediate polarity extracts. The portion of the chromatogram that shows white zones surrounded by pinkish areas denotes the $\mathrm{Rf}$ value of the active compound in each extract (Fig. 1b). In most of the extracts, more than one active compound was observed.

The minimum inhibitory concentration of the plant extracts was determined. The lower the MIC is the better is the activity [49]. Antimicrobial activity of plant extracts have been classified as good $(\mathrm{MIC}<0.1 \mathrm{mg} / \mathrm{mL})$, moderate $(0.1 \leq \mathrm{MIC} \leq 0.625 \mathrm{mg} / \mathrm{mL})$ and weak (MIC > $0.625 \mathrm{mg} / \mathrm{mL}$ ) [50]. Most of the extracts had good activity against at least two of the bacteria examined.

The Gram-negative bacteria generally had a higher resistance to the plant extracts than Gram-positive bacteria $[51,52]$. This may be attributed to the distinct feature of the morphology of cell walls of Gram-negative bacteria which, in contrast to those of Gram-positive bacteria, comprise a hydrophilic lipopolysaccharide outer layer highly resistant to the penetration of antibacterial agents, as well as the presence of some enzymes in the periplasmic space which break down antibacterial molecules [53].

Table 4 Effect of acetone crude leaf extracts of nine plants against biofilm formation by Gram-negative and Gram-positive bacteria. Inhibition of biofilm formed is expressed as percentage (\%) biofilm inhibition. The numbers $>0 \% \geq 50 \%$ show low activity, $>50 \%$ (in bold) show high activity against the bacteria. Negative values denote enhancement of biofilm [44]

\begin{tabular}{|c|c|c|c|c|c|c|}
\hline & E. coli & P. aeruginosa & S. Typhimurium & E. faecalis & B. cereus & S. aureus \\
\hline E. erythrophylla & 83 & 76 & 88 & 41 & 80 & 83 \\
\hline E. natalitia & 77 & 64 & 68 & 47 & 41 & 35 \\
\hline E. woodii & -10 & 58 & 49 & -19 & 71 & 42 \\
\hline E. umtamvunensis & 27 & 83 & 105 & 57 & 77 & 73 \\
\hline E. zeyheri & 34 & 65 & 22 & -104 & 74 & 83 \\
\hline S. legatii & 100 & 59 & 100 & 71 & 85 & 86 \\
\hline S. masukuense & 34 & -62 & 84 & 125 & 44 & -155 \\
\hline S. species A & 81 & -276 & 82 & -96 & 97 & -29 \\
\hline S. gerrardii & -15 & -125 & 122 & 114 & 146 & 68 \\
\hline Gentamicin & 83 & 75 & 81 & 88 & 84 & 96 \\
\hline
\end{tabular}


Table 5 Effect of acetone crude leaf extracts of nine plants against Gram-negative and Gram-positive bacteria after 24 and $48 \mathrm{~h}$ preformed biofilm expressed as percentage (\%) biofilm inhibition. The numbers $>0 \% \leq 50 \%$ indicates low activity, $>50 \%$ (in bold) indicates high activity against the bacteria. Negative values denote enhancement of biofilm [44]

\begin{tabular}{|c|c|c|c|c|c|c|c|c|c|c|c|c|}
\hline & \multicolumn{2}{|l|}{ E. coli } & \multicolumn{2}{|c|}{ P. aeruginosa } & \multicolumn{2}{|c|}{ S. Typhimurium } & \multicolumn{2}{|c|}{ E. faecalis } & \multicolumn{2}{|c|}{ B. cereus } & \multicolumn{2}{|c|}{ S. aureus } \\
\hline & $24 \mathrm{~h}$ & $48 \mathrm{~h}$ & $24 \mathrm{~h}$ & $48 \mathrm{~h}$ & $24 \mathrm{~h}$ & $48 \mathrm{~h}$ & $24 \mathrm{~h}$ & $48 \mathrm{~h}$ & $24 \mathrm{~h}$ & $48 \mathrm{~h}$ & $24 \mathrm{~h}$ & $48 \mathrm{~h}$ \\
\hline E. erythrophylla & -150 & -26 & -261 & -364 & -275 & 30 & -21 & -67 & -254 & -194 & 5 & -115 \\
\hline E. natalitia & 82 & -142 & -362 & -178 & 73 & 21 & -211 & -7 & -35 & -44 & -248 & 43 \\
\hline E. woodii & ND & ND & -218 & -16 & 29 & -175 & ND & ND & -179 & -171 & -147 & -488 \\
\hline E. umtamvunensis & 43 & 28 & -126 & -140 & 33 & 94 & 86 & -155 & -12 & -7 & 75 & 38 \\
\hline E. zeyheri & 237 & -4 & -263 & -65 & 341 & 66 & ND & ND & -260 & -47 & -299 & -326 \\
\hline S. legatii & -115 & -146 & -85 & -82 & -143 & -273 & 39 & 4 & -275 & -216 & 56 & -41 \\
\hline S. masukuense & 218 & 95 & ND & ND & 154 & 162 & 138 & -426 & 9 & 257 & ND & ND \\
\hline S. species A & 38 & 142 & ND & ND & 43 & 151 & ND & ND & -192 & 48 & ND & ND \\
\hline S. gerrardii & ND & ND & ND & ND & 59 & -142 & 71 & 69 & 96 & -103 & 142 & 133 \\
\hline Gentamicin & 90 & 64 & 78 & 85 & 18 & 103 & 81 & 72 & 27 & 12 & 75 & 53 \\
\hline
\end{tabular}

ND Not determined

More plant extracts from the Syzygium genus had higher activity against the Gram-negative species than those from the Eugenia genus (Table 2). Of the nine plant species, S. legatii had a broad spectrum of antibacterial activity with good activity on all the bacteria tested. With the exception of the E. zeyheri extracts, there were no statistically significant differences $(P>0.05)$ between the activity of the other extracts and gentamicin (Fig. 3).

The potency of a plant extract, referred to as the total antibacterial activity (TAA) can be determined on the basis of both its MIC in $\mathrm{mg} / \mathrm{mL}$ and extract yield in $\mathrm{mg} / \mathrm{g}$ [49]. This value gives the volume $(\mathrm{ml})$ to which the extract obtained

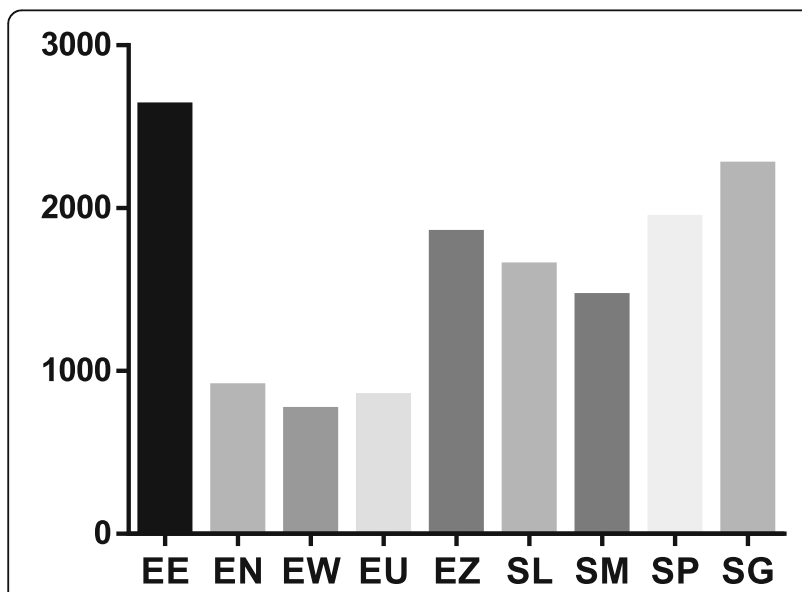

Fig. $\mathbf{3}$ The mean MIC in $\mathrm{mg} / \mathrm{ml}$ of the acetone leaf extracts of the nine plants against six different bacterial species. $\mathrm{EE}=$ Eugenia erythrophylla, EN = Eugenia natalitia, EW = Eugenia woodii, EU = Eugenia umtamvunensis, EZ = Eugenia zeyheri, SL = Syzygium legatii, $\mathrm{SM}=$ Syzygium masukuense, $\mathrm{SP}=$ Syzygium sp., $\mathrm{SG}=$ Syzygium gerrardii, $\mathrm{G}=$ Gentamicin (positive control). The negative control (acetone) was higher than 25\% (higher than $198 \mathrm{mg} / \mathrm{ml}) .{ }^{*}=$ shows statistical significant differences $(p<0.05)$ between Gentamicin and Eugenia zeyheri from one g of plant material can be diluted and still be able to inhibit the bacteria. In this study, E. zeyheri had the best mean TAA of $2628 \mathrm{~mL} / \mathrm{g}$ due to the large extract yield. This means that if $2.628 \mathrm{~L}$ of the solvent is added to the quantity extracted from $1 \mathrm{~g}$ of the plant, bacterial growth can still be inhibited. The TAA is useful to determine the most suitable plant extract for compound isolation and bioprospecting [26].

Although it is often wrongly assumed that plant extracts and other natural products are safe, it is necessary to determine their cytotoxicity to provide scientific evidence whether they are safe or not [48]. A plant extract is considered to be highly cytotoxic when the $\mathrm{LC}_{50}$ is $20 \mu \mathrm{g} / \mathrm{mL}$ and below [54]. It should however be borne in mind that in vitro cellular toxicity may not equate to whole animal toxicity because different factors such as gut interactions and bioavailability play a role. Therefore, acute and chronic animal toxicity is needed to determine the toxicity of the extracts [55]. All of the plant extracts investigated had relatively low cytotoxicity with $\mathrm{LD}_{50}$ values higher than the predetermined cut-off point $(20 \mu \mathrm{g} / \mathrm{mL})$ (Table 3 ).

It is important to consider the selectivity index (SI) of a plant extract. A SI value greater than 1 means that the extract is more toxic to the pathogen than to normal body cells. The higher the SI value, the safer is the plant extract and the higher the potential to be developed as a safe herbal product. The extracts of many of the plants investigated in this study have potential to be developed into useful products to control antimicrobial infections by herbal remedies. Alternatively, isolation of active compounds can form a template for the development of new drugs.

Bacterial biofilm remains a global threat to health due to high refractoriness to treatment and the ability to aggravate nosocomial infections. Hence, search for novel efficacious molecules to tackle this problem is a priority 
[56]. In this study, the activities of the plant extracts were tested against the biofilms of the bacteria species. This appears to be the first study to determine the antibiofilm activity of the selected plant extracts. The ability of antibacterial agents to inhibit formation of or destruction of biofilms hold promise for reducing colonization of surfaces and epithelial mucosa by microbes [57].

With the exception of $E$. woodii and S. gerrardii extracts, all the other extracts prevented the formation of E. coli biofilms. All the plant extracts prevented S. Typhimurium and B. cereus biofilms. Syzygium legatii, S. masukuense, and $S$. species A had an excellent MIC of $0.08 \mathrm{mg} / \mathrm{mL}$ against planktonic $P$. aeruginosa. With the exception of S. legatii no Syzygium species was able to prevent biofilm production in $P$. aeruginosa. All the $E u-$ genia species in this study inhibited attachment of $P$. aeruginosa by over $50 \%$ indicating a good antiattachment property. The attachment of $S$. aureus and $E$. faecalis was also inhibited by most of the plant extracts.

The excellent ability of the plant extracts to interfere with the initial stage of biofilm formation of the six bacterial isolates may be attributed to interference with forces (such as Brownian, sedimentation, Lifshitz-Van der Waals and electrostatic interaction forces) that favour the deposition and adherence of bacteria to surfaces [58]. Also, since certain organic and inorganic molecules and other nutrients are important for cell growth and hence cell adhesion [59], it is possible that the plant extracts may inhibit the availability of nutrients. The active plant extracts may hold promise for reduction of colonization surfaces and various epithelial of the body, thereby preventing infections. A similar observation was made in a previous study on the ability of acetone and ethanol crude extracts of Psidium guajava (Myrtaceae) to prevent attachment of Streptococcus mutans, a known biofilm former on oral surfaces [60]. In another study, leaf extracts of E. leitonii, E. brasiliensis, E. myrcianthes and E. involucrate had good antiadhesive activity against Candida albicans [31]. This shows that Eugenia and Syzygium species possess compounds with promising antibiofilm activity.

This study assessed the ability of plant extracts to destroy or prevent further formation of established biofilms at $24 \mathrm{~h}$ and $48 \mathrm{~h}$. Only plant extracts with anti-attachment activity was included in this study.

The plant extract of $S$. masukuense had excellent activity against the $24 \mathrm{~h}$ and $48 \mathrm{~h} \mathrm{E}$. coli biofilms. Compounds from this plant extract may be useful to combat diseases such as otitis media and urinary tract infections caused by E. coli is biofilms, at acute or chronic stages [61].

The anti-Salmonella activity shown by the plants even after $48 \mathrm{~h}$ biofilm highlights their potential for control of Salmonella biofilms. In a similar study [62], natural compounds such as eugenol, thymol and carvacol inhibited $S$. Typhimurium biofilm formations by more than $50 \%$. Possible applications may be spraying of vegetables by natural compounds for decontamination of food pathogens such as Salmonella [63].

Enterococcus faecalis is a common biofilm former usually implicated in urinary tract infections, wound infections, and dental infections [64]. The extracts of Eugenia umtamvunensis and $S$. masukuense had good activity against the $24 \mathrm{~h}$ E. faecalis biofilm while $S$. gerrardii had excellent activity against both $24 \mathrm{~h}$ and $48 \mathrm{~h}$ biofilms. There is a potential to develop herbal products from these plant extracts as mouth rinses for oral care, as well as for topical applications to treat wounds in medical and veterinary care. It may be possible to isolate an active compound against E. faecalis biofilm from S. gerrardii.

Syzygium gerrardii had the best activity against $24 \mathrm{~h}$ and $48 \mathrm{~h} \mathrm{~S}$. aureus biofilms. In a related study, the essential oil from Syzygium aromaticum had good activity against Staphylococci biofilms associated with mastitis in the dairy industry [65]. Syzygium gerrardii may be a good candidate for the development of anti-staphylococcal products that may find application as sanitizers to clean surfaces. Also, it may contain active compounds that may form template for the development of potent drugs to treat staphylococcal infections in humans and animals.

The biofilm of $P$. aeruginosa was the most difficult to eradicate among all the tested bacteria. Although some of the extracts had a good potential to prevent attachment, none was able to get rid of pre-formed biofilms after 24 and $48 \mathrm{~h}$. In contrast, most of the extracts had good minimum inhibitory activity against $P$. aeruginosa in the quantitative minimum inhibitory assay. Pseudomonas aeruginosa is a notorious biofilm producer and its biofilms cause the highest number of acute and chronic infections, especially in the excretory and respiratory systems [66, 67], and it can also colonize medical devices and body implants [12]. The enhancement of biofilm production by some of the extracts confirm initial reports that some natural compounds may promote the growth of microbes [68].

Compounds present in the plant extracts may be responsible for the various antibiofilm activities observed in this study. In a recent review, isolated natural compounds from plants had antibiofilm activity against different bacterial pathogens [69]. In the future, attempts will be made to isolate compounds which may responsible for the antibiofilm effects of the active plant extracts.

Generally, it was more difficult to eradicate pre-existing biofilms by the extracts in this study. Some reports have also noted that it is less difficult to inhibit cell attachment than to get rid of established biofilm [70, 71]. This confirms that pathogens are able to resist the action of antimicrobials more when they exist in biofilms and their infections are able to persist on different biotic and abiotic surfaces [61]. Factors which cause resistance in biofilms include presence of an extracellular polymetric matrix which 
causes strong attachment of microbes to surfaces and low antibiotic penetration or increased activity of efflux pumps which expel antimicrobial agents from cells [10]. The plant extracts may have interfered with any of these factors. The plant extracts may have also interfered with the cell to cell communication strategies (quorum sensing) of the bacteria, thereby reducing biofilm formation [72].

The activity of the plant extracts against biofilms at different stages of development highlights their potential usefulness in clinical applications. Such applications may help to enhance the immunological defense of infected hosts against bacterial cell populations, especially those in biofilms, and subsequent host clearance and reduction of disease symptoms [66]. Some of the active extracts may potentially be developed into herbal products which can be useful in alleviating diarrhoeal symptoms and enhancing productivity when added to livestock feed as replacement to antibiotics. The use of antibiotics as additives to livestock feeds has been banned in many countries worldwide due to issues of transfer of antimicrobial resistance to humans [73]. More studies are needed to elucidate the mechanism of antibiofilm action of the active plant extracts in this study.

\section{Conclusions}

Little was known about the antimicrobial activities of the selected plants in this study. Our results showed that the crude extracts of the plants had good activity on the planktonic and sessile forms of the bacterial species investigated. Many of the plants had low toxicity which makes them good candidates for possible development into herbal products or for isolation of novel pure compounds that can serve as templates for new antimicrobial drugs. The crude extracts of some of the plants have potential as phytogenic feed additives that can replace in-feed single compound antibiotics commonly added to livestock feeds as growth promoters, especially when animal feed trials are performed. Although we used bacterial strains recommended by the Clinical and Laboratory Standards Institute to compare activity of different antibiotic substances, it will be interesting to determine the activities of these plants against clinical bacterial isolates to further assess their relevance for use in clinical conditions. It is imperative to determine the mode of antibacterial action of the extracts and how they act on the different pathogens. To a reasonable extent, our findings have provided credence to the value of selecting plants for antimicrobial investigation on a taxonomic basis [25]. These results may stimulate further biological research on these and other under-explored plant species in the Myrtaceae family, especially those native to southern Africa.

\section{Abbreviations}

ATCC: American Type Culture Collection; CFU: Colony forming unit; DMSO: Dimethyl sulphoxide; INT: $\rho$-iodonitrotetrazolium violet; LC $^{50}$ : Lethal concentration (50\%); MIC: Minimum inhibitory concentration; MTT: 3-(4,5dimethylthiazol-2-yl)-2, 5-diphenyltetrazolium bromide; OD: Optical density; PBS: Phosphate buffer saline; SD: Standard deviation; SI: Selectivity index; TAA: Total antibacterial activity

\section{Acknowledgements}

The curators of the Lowveld National Botanical Gardens in Nelspruit and the University of Pretoria Botanical Garden allowed us to collect plant material. Ms. Magda Nel and Ms. Elsa Van Wyk of the HGWJ Schweickerdt Herbarium of the University of Pretoria assisted in preparing voucher specimens.

\section{Authors' contributions}

IMF carried out the research and wrote the first draft of the manuscript. AAA assisted in the research and revised the manuscript. FOF revised the manuscript. LJM guided the research project and revised the manuscript. JNE helped with plant collection, co-supervised the research, revised and submitted the manuscript. All authors read and approved the final manuscript.

\section{Funding}

The South African National Research Foundation, The World Academy of Science (Grant No. 99808) and the University of Pretoria funded IMF's study. The National Research Foundation providing research funding to LJM (Grant No 105993).

\section{Availability of data and materials}

The datasets used and/or analyzed during the current study are available from the corresponding author on reasonable request.

Ethics approval and consent to participate

Not applicable.

Consent for publication

Not applicable.

\section{Competing interests}

No financial or non-financial competing interests. Prof. Jacobus N Eloff is a member of the editorial board of BMC Complementary and Alternative Medicine.

\section{Author details}

${ }^{1}$ Phytomedicine Programme, Faculty of Veterinary Science, University of Pretoria, Private Bag X04, Onderstepoort 0110, South Africa. ${ }^{2}$ Department of Veterinary Tropical Diseases, Faculty of Veterinary Science, University of Pretoria, Private Bag X04, Onderstepoort 0110, South Africa. ${ }^{3}$ Emergency Centre for Transboundary Animal Diseases-Food and Agriculture Organization of the United Nations (ECTAD-FAO), House H. Sida, Ali Hassan Mwinyi Road, Ada Estate, Dar es Salaam, Tanzania.

Received: 15 October 2018 Accepted: 3 June 2019

Published online: 20 June 2019

\section{References}

1. Sr H, Davoodi H. Herbal plants and their derivatives As growth and health promoters in animal nutrition. Vet Res Commun. 2011;35(3):169-80.

2. Hoelzer $K$, Wong N, Thomas J, Talkington $K$, Jungman E, Coukell A. Antimicrobial drug use in food-producing animals and associated human health risks: what, and how strong, is the evidence? BMC Vet Res. 2017;13(1):211.

3. Mj C, llanko A, Blonk B, le C. Developing New Antimicrobial Therapies: Are Synergistic Combinations Of Plant Extracts/Compounds With Conventional Antibiotics The Solution? Pharmacogn Rev. 2017;11(22):57.

4. Lowrence R, Ramakrishnan A, Sundaramoorthy N, Shyam A, Mohan V, Subbarao H, Ulaganathan V, Raman T, Solomon A, Nagarajan S. Norfloxacin salts of carboxylic acids curtail planktonic and biofilm mode of growth in Eskape pathogens. J Appl Microbiol. 2018;124(2):408-22.

5. Yelin I, Kishony R. Antibiotic Resistance. Cell. 2018;172(5):1136. 
6. $\| \mathrm{E}, \mathrm{Fs} B, \mathrm{Lj} M$, Jn E. The antibacterial activity of extracts of nine plant species with good activity against Escherichia Coli against five other Bacteria and cytotoxicity of extracts. BMC Complement Altern Med. 2017;17(1):133.

7. Tacconelli E, Carrara E, Savoldi A, Harbarth S, Mendelson M, Monnet DL, Pulcini C, Kahlmeter G, Kluytmans J, Carmeli Y, et al. Discovery, Research, And Development Of New Antibiotics: The Who Priority List Of AntibioticResistant Bacteria And Tuberculosis. Lancet Infect Dis. 2018;18(3):318-27.

8. De La Fuente-Núñez C, Korolik V, Bains M, Nguyen U, Ebm B, Horsman S, Lewenza S, Burrows L, Rew H. Inhibition Of Bacterial Biofilm Formation And Swarming Motility By A Small Synthetic Cationic Peptide. Antimicrobial Agents And Chemotherapy. 2012;56(5):2696.

9. $\mathrm{Mm}$ B, Rohloff J. Antibiofilm activity of essential oils and plant extracts against Staphylococcus Aureus and Escherichia Coli biofilms. Food Microbiol. 2016;61:156-64.

10. Jamal M, Ahmad W, Andleeb S, Jali F, Imran M, Ma N, Hussain T, Ali M, Rafiq M, Ma K. Bacterial biofilm and associated infections. J Chin Med Assoc. 2018;81(1):7-11.

11. Ks L, Lou Z, Letsididi R, Mohammed K, BI M. Antimicrobial and Antibiofilm effects of trans-Cinnamic acid Nanoemulsion and its potential application on lettuce. Lwt. 2018;94:25-32.

12. Lebeaux D, Ghigo J-M, Beloin C. Biofilm-related infections: bridging the gap between clinical management and fundamental aspects of recalcitrance toward antibiotics. Microbiol Mol Biol Rev. 2014:78(3):510-43.

13. Chakraborty S, Dutta T, De A, Das M, Ghosh S. Impact of bacterial biofilm in veterinary medicine: an overview. Int J Curr Microbiol App Sci. 2018;7(4):3228-39.

14. Petruzzi B, Ra D, Leroith T, Np E, Fw P, Tj I. Biofilm formation and avian immune response following experimental acute and chronic avian cholera due to Pasteurella Multocida. Vet Microbiol. 2018;222:114-23.

15. Mc D, Sandhu P, Gupta P, Rudrapaul $P$, Uc D, Tribedi $P$, Akhter $Y$, Bhattacharjee S. Attenuation Of Pseudomonas aeruginosa Biofilm Formation By Vitexin: A Combinatorial Study With Azithromycin And Gentamicin. Sci Rep. 2016;6:23347.

16. Md M, JI DP, Díez-Aguilar M, Guinea J. Microbiological diagnosis of biofilmrelated infections. Enferm Infec Micr Cl. 2018;36(6):375-81.

17. De La Fuente-Núñez C, Cardoso M, De Souza CE, Ol F, Rew H. Synthetic Antibiofilm peptides. Biochim Biophys Acta Biomembr. 2016;1858(5):1061-9.

18. Betts JW, Hornsey M, La Ragione Rm: Novel Antibacterials: Alternatives To Traditional Antibiotics. In: Advances In Microbial Physiology. Edn.: Academic Press; 2018.

19. Dg B, Lister T, TI M-D. New natural products As new leads for antibacterial drug discovery. Bioorganic Med Chem Lett. 2014;24(2):413-8.

20. Romulo A, Ea Z, Rondevaldova J, Kokoska L. Screening of in vitro antimicrobial activity of plants used in traditional Indonesian medicine. Pharm Biol. 2018;56(1):287-93.

21. Icdo R, Ega M, Rt C, Morais-Costa F, Sant'anna Fm D, Ms P, Mr DS, Er D. Plants Of The Cerrado With Antimicrobial Effects Against Staphylococcus Spp. And Escherichia coli From Cattle. Bmc Vet Res. 2018;14(1):32.

22. Oo O, Pa S, Ps F. Antimicrobial and antiprotozoal activities of twenty-four Nigerian medicinal plant extracts. S Afr J Bot. 2018;117:240-6.

23. Am Q, Ma F-A, Md G-G, De La Puerta R. Potential Therapeutic Applications Of The Genus Annona: Local and traditional uses and pharmacology. J Ethnopharmacol. 2018:225:244-70.

24. Eloff Jn, Mcgaw Lj: Application Of Plant Extracts And Products In Veterinary Medicine. In Ahmad, I. And Aqil F (Edts.), New Strategies Combating Bacterial Infection Pp 205-228, Wiley-Vch, Weinheim; 2008.

25. Pauw E, Jn E. Which Tree Orders In Southern Africa Have The Highest Antimicrobial Activity And Selectivity Against Bacterial And Fungal Pathogens Of Animals? Bmc Complement Altern Med. 2014;14(1):317.

26. Kotzé $M$, Jn E. Extraction of antibacterial compounds from Combretum Microphyllum (Combretaceae). S Afr J Bot. 2002;68(1):62-7.

27. Jn E, le A, Lj M. Solvent-solvent fractionation can increase the antifungal activity of a Melianthus Comosus (Melianthaceae) acetone leaf extract to yield a potentially useful commercial antifungal product. Ind Crop Prod. 2017;110:103-12.

28. Sf B, Ac R, Cldo P, Rcb DG, GI S, Ap SF, JIm S. Extraction, purification and structural characterization of a Galactoglucomannan from the Gabiroba fruit (Campomanesia Xanthocarpa berg), Myrtaceae Family. Carbohydr Polym. 2017:174:887-95

29. Rb K, Md R, Vk K, Ss F, Egt K, Swapna S, Ramesh B, Ca R. Antihyperglycemic and Antihyperlipidemic activities of methanol: water (4: 1) fraction isolated from aqueous extract of Syzygium Alternifolium seeds in Streptozotocin induced diabetic rats. Food Chem Toxicol. 2010;48(4):1078-84.

30. Am DS, Cf DO, Vb DO, Fcm B, Og M, Md M. Traditional Uses, Phytochemistry, And Antimicrobial Activities Of Eugenia Species-A Review. Planta Med. 2018:1-17.
31. Jdco S, la F, Jg L, Infante J, Sm DA, PI R. Unexplored endemic fruit species from Brazil: Antibiofilm properties, insights into mode of action, and systemic toxicity of four Eugenia Spp. Microb Pathog. 2017;105:280-7.

32. Yuan W, Yuk H-G. Antimicrobial efficacy of Syzygium Antisepticum plant extract against Staphylococcus Aureus and methicillin-resistant S. Aureus and its application potential with cooked chicken. Food Microbiol. 2018;72:176-84.

33. Jg L, Jdco S, Franchin M, Bd N, la F, Infante J, Jar P, Sm DA, PI R. Bioprospection of Eugenia Brasiliensis, a Brazilian native fruit, As a source of anti-inflammatory and Antibiofilm compounds. Biomed Pharmacother. 2018;102:132-9.

34. Jasmine R, Kumar S. Cytotoxic activity of a Glaucoside from Eugenia Jambolana against Mcf-7 cells. Indian J Pharmacol. 2016;48(1):99-100.

35. Migues I, Baenas N, Gironés-Vilaplana A, Mv C, Heinzen H, Da M. Phenolic Profiling And Antioxidant Capacity Of Eugenia uniflora L.(Pitanga) Samples Collected In Different Uruguayan Locations. Foods. 2018:7(5).

36. Gajera H, Sn G, Dg H, Patel S, Golakiya B. Antidiabetic and antioxidant functionality associated with phenolic constituents from fruit parts of indigenous black Jamun (Syzygium Cumini L.) landraces. J Food Sci Technol. 2017;54(10):3180-91.

37. Ss M, Oss A-H, Ma A, Wa A. Syzygium jambos (L.) Alston (Myrtaceae), A New Record Introduced To The Flora Of Yemen. J Biol Earth Sci. 2014;4(1):52-6.

38. In E, Lj M. Plant extracts used to manage bacterial, fungal and parasitic infections in southern Africa. Modern Phytomedicine: Turning Medicinal Plants Into Drugs. 2006:97-121.

39. In E. Antibacterial activity of Marula (Sclerocarya Birrea (a. rich.) Hochst. Subsp. Caffra (Sond.) Kokwaro) (Anacardiaceae) bark and leaves. J Ethnopharmacol. 2001;76(3):305-8.

40. Wj B, Rm K. The use of tetrazolium salts in bioautographic procedures. J Chromatogr. 1972;64(1):182-4.

41. In E. A sensitive and quick microplate method to determine the minimal inhibitory concentration of plant extracts for Bacteria. Planta Med. 1998;64(08):711-3.

42. In E, Masoko P, Picard J. Resistance of animal fungal pathogens to solvents used in bioassays. S Afr J Bot. 2007;73(4):667-9.

43. In E. On Expressing The Antibacterial Activity Of Plant Extracts-A Small First Step In Applying Scientific Knowledge To Rural Primary Health Care. S Afr J Sci. 2000;96:3.

44. Sandasi M, Leonard C, Viljoen A. The effect of five common essential oil components on Listeria Monocytogenes biofilms. Food Microbiol. 2008;19(11):1070-5.

45. Djordjevic D, Wiedmann M, Mclandsborough L. Microtiter plate assay for assessment of Listeria Monocytogenes biofilm formation. Appl Environ Microbiol. 2002:68(6):2950-8.

46. Mosmann T. Rapid colorimetric assay for cellular growth and survival: application to proliferation and cytotoxicity assays. J Immunol Method. 1983;65(1-2):55-63.

47. Lj M, Van Der Merwe D, Jn E. In Vitro anthelmintic, antibacterial and cytotoxic effects of extracts from plants used in south African Ethnoveterinary medicine. Vet J. 2007;173(2):366-72.

48. Jp D, Ao A, Lj M, Jn E. Antimycobacterial activity against different pathogens and selectivity index of fourteen medicinal plants used in southern Africa to treat tuberculosis and respiratory ailments. S Afr J Bot. 2016;102:70-4.

49. In E. Quantification the bioactivity of plant extracts during screening and bioassay guided fractionation. Phytomedicine. 2004;11(4):370-1.

50. Kuete V. Potential of Cameroonian plants and derived products against microbial infections: a review. Planta Med. 2010;76(14):1479-91.

51. Biswas B, Rogers K, Mclaughlin F, Daniels D, Yadav A. Antimicrobial activities of leaf extracts of guava (Psidium Guajava L.) on two gram-negative and gram-positive Bacteria. Int J Microbiol. 2013;2013.

52. Boulekbache-Makhlouf L, Slimani S, Madani K. Total phenolic content, antioxidant and antibacterial activities of fruits of Eucalyptus Globulus cultivated in Algeria. Ind Crop Prod. 2013;41:85-9.

53. Djihane B, Wafa N, Elkhamssa S, Maria AE, Mihoub ZM. Chemical constituents of Helichrysum Italicum (Roth) G. Don essential oil and their antimicrobial activity against gram-positive and gram-negative Bacteria, filamentous Fungi and Candida Albicans. Saudi Pharm J. 2017;25(5):780-7.

54. Kuete V, Krusche B, Youns M, Voukeng I, Fankam AG, Tankeo S, Lacmata S, Efferth T. Cytotoxicity of some Cameroonian spices and selected medicinal plant extracts. J Ethnopharmacol. 2011;134(3):803-12.

55. As A, Ee E, Moodley N, Lj M, Naidoo V, Jn E. The antimicrobial, Antioxidative, anti-inflammatory activity and cytotoxicity of different fractions of four south African Bauhinia species used traditionally to treat Diarrhoea. J Ethnopharmacol. 2012;143(3):826-39.

56. Nostro A, Guerrini A, Marino A, Tacchini M, Di Giulio M, Grandini A, Akin M, Cellini L, Bisignano G, Saraçoğlu H. In vitro activity of plant extracts against biofilm-producing food-related Bacteria. Int J Food Microbiol. 2016;238:33-9. 
57. Bavington C, Page C. Stopping bacterial adhesion: a novel approach to treating infections. Respiration. 2005;72(4):335-44.

58. Tiwari M, Donelli G, Tiwari V. Strategies for combating bacterial biofilms: a focus on anti-biofilm agents and their mechanisms of action au - Roy, Ranita. Virulence. 2018;9(1):522-54.

59. Sandasi M, Leonard C, Viljoen A. The in vitro Antibiofilm activity of selected culinary herbs and medicinal plants against listeria monocytogenes. Lett Appl Microbiol. 2010;50(1):30-5.

60. Av G, Aa S, Kasulkar A. Investigation of biofilm inhibition activity and antibacterial activity of Psidium Guajava plant extracts against Streptococcus Mutans causing dental plaque. Int J Curr Microbiol App Sci. 2014;3(9):335.

61. De La Fuente-Núñez C, Reffuveille F, Fernández L, Rew H. Bacterial biofilm development As a multicellular adaptation: antibiotic resistance and new therapeutic strategies. Curr Opin Microbiol. 2013;16(5):580-9.

62. Miladi H, Zmantar T, Kouidhi B, Chaabouni Y, Mahdouani K, Bakhrouf A, Chaieb K. Use of Carvacrol, thymol, and eugenol for biofilm eradication and resistance modifying susceptibility of Salmonella Enterica Serovar typhimurium strains to Nalidixic acid. Microb Pathog. 2017;104:56-63.

63. Ganesh V, Hettiarachchy NS, Ravichandran M, Johnson MG, Griffis CL, Em M, If M, Ricke SC. Electrostatic sprays of food-grade acids and plant extracts are more effective than conventional sprays in decontaminating Salmonella typhimurium on spinach. J Food Sci. 2010;75(9):M574-9.

64. Lee P, Tan KS. Effects of epigallocatechin Gallate against Enterococcus Faecalis biofilm and virulence. Arch Oral Biol. 2015:60(3):393-9.

65. Pe B, Ncc S, Ecr B, Fernandes A, Jp A, Doyama J, Jl G, Mv S, FitzgeraldHughes D, VIm R. Effect of essential oils of Syzygium Aromaticum and Cinnamomum Zeylanicum and their major components on biofilm production in Staphylococcus Aureus strains isolated from Milk of cows with mastitis. J Dairy Sci. 2015;98(9):5899-904.

66. Sathiya Deepika M, Thangam R, Sakthidhasan P, Arun S, Sivasubramanian S, Thirumurugan R. Combined effect of a natural flavonoid Rutin from Citrus Sinensis and conventional antibiotic gentamicin on Pseudomonas Aeruginosa biofilm formation. Food Microbiol. 2018:90:282-94.

67. Mn A, Porse A, Moa S, Hoiby N, Ciofu O. Evolution Of Antibiotic Resistance In Biofilm And Planktonic P. aeruginosa Populations Exposed To Sub-Inhibitory Levels Of Ciprofloxacin. Antimicrob Agents Chemother. 2018;62(8):E00320-18.

68. Sa S, Me A, Sm H, Ar A. Chemical Composition, Antimicrobial And Antibiofilm Activity Of The Essential Oil And Methanol Extract Of The Mediterranean Cypress (Cupressus sempervirens L.). Bmc Complement Altern Med. 2014;14(1):179.

69. Song $X$, Xia $Y-X$, He Z-D, Zhang $H-J$. A review of natural products with antibiofilm activity. Curr Org Chem. 2018;22(8):789-817.

70. Cerca N, Martins S, Gb P, Oliveira R, Azeredo J. The relationship between inhibition of bacterial adhesion to a solid surface by sub-Mics of antibiotics and subsequent development of a biofilm. Res Microbiol. 2005;156(5-6):650-5.

71. Sandasi M, Leonard C, Van Vuuren S, Viljoen A. Peppermint (Mentha Piperita) inhibits microbial biofilms In Vitro. S Afr J Bot. 2011;77(1):80-5.

72. Merghni A, Noumi E, Hadded O, Dridi N, Panwar H, Ceylan O, Mastouri M, Snoussi M. Assessment of the Antibiofilm and Antiquorum sensing activities of Eucalyptus Globulus essential oil and its Main component 1, 8-cineole against methicillin-resistant Staphylococcus Aureus strains. Microb Pathog. 2018;118:74-80

73. Am S, Beller E, Glasziou P, Clark J, Rw R, Byambasuren O, Bakhit M, Sw P, Trott $D, C d$ M. Is antimicrobial administration to food animals a direct threat to human health? A rapid systematic review. Int J Antimicrob Agents. 2018; 52(3):316-23.

\section{Publisher's Note}

Springer Nature remains neutral with regard to jurisdictional claims in published maps and institutional affiliations.

Ready to submit your research? Choose BMC and benefit from:

- fast, convenient online submission

- thorough peer review by experienced researchers in your field

- rapid publication on acceptance

- support for research data, including large and complex data types

- gold Open Access which fosters wider collaboration and increased citations

- maximum visibility for your research: over $100 \mathrm{M}$ website views per year

At BMC, research is always in progress.

Learn more biomedcentral.com/submissions 